\title{
Creating a common symbol classification for a new historical geoportal of Poland
}

\begin{abstract}
The crowd-sourcing approach should be implemented into a new historical geoportal of Poland due to its increasing potential in WebGIS. Registered users will be able to acquire spatial data from various map series. As it requires feature class harmonization, a common symbol classification should be proposed. It will be based on chosen topographic maps of Polish land from the $19^{\text {th }}$ and $20^{\text {th }}$ centuries. Feature classes derived from archival maps will be standardized and reclassified, but with no information lost. This will be done in four steps which require: data acquisition, map content harmonization, feature class typification and attribute table elaboration. In addition, four methods of data harmonization can be distinguished: symbol sequence, semantic analogies, spatial relations and a combined method. The paper covers the elaboration of two thematic layers - roads and railways based on three topographic maps (Austrian 1:75 000, German 1:100 000, Russian 1: 126 000)
\end{abstract}

Keywords

Historical GIS • hGIS • WebGIS • cartographic data modelling

(C) University of Warsaw - Faculty of Geography and Regional Studies
Tomasz Panecki

Department of Cartography

Faculty of Geography and Regional Studies

University of Warsaw

e-mail: tpanecki@uw.edu.pl

Received: 3 December 2013

Accepted: 8 April 2014
Introduction

Geographic Information Systems (GIS) are no longer the domain of the natural sciences. Owing to a trend in the so called "digital humanities" and due to GIS potential as a powerful research tool, historians have started employing spatial analysis in their research. This includes visualizations such as thematic maps (Szady 2010). However, Historical GIS (hGIS) remains a new branch of geoinformatics and thus its methodology and range of research is still under discussion (Gregory 2005; Gregor \& Healey 2007; Knowles 2007).

Although analyses performed in hGIS appear to be similar to those using modern-day information, one needs to be aware of major differences arising from the nature of the data which are likely to be inconsistent, unharmonized and incoherent. Therefore, it is necessary to lay common foundations for future analysis which can facilitate revision of studies made before the hGIS approach, answer unaddressed questions or help the researchers to ask completely new ones (Gregory \& Healey 2007).

It has been noted that the Internet appears to be a natural environment for geohistory as it provides a possibility of wide and fast information dissemination as well as allowing users' active participation in certain projects (Szady 2008). Internet platforms gathering historical spatial data such as archival maps, census data and geotagged images have been implemented in many countries. They vary in terms of content, functionality and architecture, but their main purpose is to provide spatio-temporal information to all who may be interested (Gregory \& Southall 2000).

Public participation has become a vivid trend in WebGIS and an important factor supporting historical geoportal development. It entails that end-users should be granted wide access to the data from on-line geodatabases and consequently not only be able to browse but also alter it, i.e. create features, update attributes, etc. (Dunn 2007). The OpenStreetMap (OpenStreetMap 2013) website is a perfect example of a "crowd-sourcing" project: a world map based on satellite images and GPS measurements created by Internet users.

So far, a certain functionality of the National Historical Geographic Information System from the USA (National Historical Geographic Information System 2013) can be subsumed under this approach. Users are allowed to create and share slideshows based on historical thematic maps, e.g. population density over the years. "Crowd-sourcing" tools are also being developed by the Polish company "Cartomatic" (Cartoninjas 2013).

"Crowd sourcing" brings both opportunities and limitations, thus these ideas are not yet widespread among geohistorical platforms. On the one hand, it can involve both specialists and volunteers who can also significantly contribute to the project. On the other, management is more difficult because it is necessary to double-check the data collected by users (in terms of topological and semantic correctness). In addition, the elaboration of a platform itself becomes a more demanding task as it is crucial to provide a consistent and harmonized framework. If certain thematic layers from various maps are to be vectorized by users and thus stored in a spatial database, a sort of common symbol classification should be developed.

The aim of this study is to propose a methodology of common symbol classification development of archival maps for the purpose of its application to the historical geoportal. It will facilitate geohistorical analysis combining previous "crowd- 
sourcing" ideas with the concept of a historical geoportal. The fact of archival map inconsistency in the field of symbology has been noted by cartographers (Gregory \& Healey 2007; Zachwatowicz 2012), although there have been no significant attempts to harmonize historical spatial data. However, some research has been conducted in terms of modern data integration, e.g. sharing map symbols for emergency management (Robinson et al. 2013).

The Polish historical geoportal: opportunities and constraints

The idea of collecting spatio-temporal data from Internet users should definitely be taken into consideration when elaborating the concept of the Polish historical geoportal. The project will be based on the georeferenced archival maps series from the $19^{\text {th }}$ and $20^{\text {th }}$ centuries covering Poland and thus making it possible to compare changes in geohistorical landscape over almost 200 years. In addition, it would be possible for registered users to digitize features from various thematic layers, such as road networks, railways or land cover. Source maps will differ in terms of scale, date of issue and country of publication making all analysis more complex and detailed. Objects created that way would be placed into a specifically designed geodatabase taking into account certain characteristics, i.e. object type and geometry, date of establishment, data source or any other necessary attributes and metadata (Gołębiowska et al. 2012).

Working with historical spatial data requires an awareness of Poland's political situation in the $19^{\text {th }}$ and $20^{\text {th }}$ centuries. From 1795 to 1918 Poland did not exist as a sovereign state and - as a consequence - there were no Polish institutions, political life, education and cohesive map series (Chwalba 2005).

This lack of homogeneity which initially appears to be a drawback can be turned into a huge advantage, as Polish lands were covered independently with maps by three states - Austria, Prussia (Germany) and Russia. Therefore, geohistorical analysis can be based not only on a single map series made at different scales at the same time, but also on various cartographical resources developed by other countries. However, it is crucial to be aware of major differences between archival maps, especially if we take into consideration the symbology layers, e.g. diverse object classification methods (Krassowski \& Tomaszewska 1979).

Platform functionality enriched with "crowd-sourcing" functionality will require a specific approach to archival maps. As a potential data source for the WebGIS platform, maps developed in the last 200 years have to be thoroughly analyzed in terms of projections, content, coverage and - last but not least - symbol classification.

\section{Common symbol classification}

Symbol classification is especially vulnerable to incoherence because of the various criteria used by cartographers to classify objects within thematic layers, especially on $19^{\text {th }}$ and early $20^{\text {th }}$ century maps. These were subjected to change not only over the years, when some of them evolved due to technical progress (e.g. roads or industry) but also because of cultural differences: different criteria were considered important by various mapmakers from various countries. However, these remarks do not concern archival maps only, as those elaborated nowadays can bear the same burden (Kent \& Vujakovic 2009).

Lack of homogeneity can cause a number of problems when analysing the geohistorical landscape (Zachwatowicz 2012). Such analysis will be possible after harmonizing the content of the maps by developing a semantically consistent symbol classification for all given maps. This can also be termed a "metalegend" (meta - a Greek word for "beyond" + legend).

The "metalegend" does not replace former map symbol descriptions; its purpose is to set up a new framework within historical spatial data. Incoherent feature classes acquired from archival maps are to be assigned to new, semantically consistent categories. However, the criteria used for the "metalegend" elaboration will be based on those used previously by cartographers as it is necessary to avoid presentism in historical data analysis (Spoerhase 2008).

The purpose of the universal symbol classification is to facilitate geohistorical research across the $19^{\text {th }}$ and $20^{\text {th }}$ centuries, thus the structure of the "metalegend" must be subordinated to this concept. Road networks may be taken as a case study. The roads' importance and significance are the most crucial criteria that will allow spatio-temporal analysis. This classification would become a sort of typology, where particular feature classes derived from archival maps would be assigned to new categories based on comparable criteria. The remaining information from archival maps (either qualitative or functional) would be stored in the database as attributes.

Eventually, the common symbol classification will become a part of a cartographic data model which is a formalized description of all feature classes taken into account, their attributes and spatial relations stored in the UML notation (Buckley, Frye \& Buttenfield 2005). The cartographic data model allows spatial data to be managed more effectively, although it is essential to harmonize geohistorical information before proceeding to further studies.

\section{Workflow}

"Metalegend" implementation can be divided into four stages. The first covers data acquisition (i.e. feature classes and their descriptions from archival maps) for the eventual universal symbol classification. The best scenario is when the map legend is attached directly to the analysed map sheets. Since topographic map series were being developed over a substantial period of time by military institutions, the object classification methods were also subject to change. Hence, the symbol description attached to the particular map sheet should guarantee the consistency between the objects presented on the map and their description on the legend.

On the other hand, if the map legend was attached to all of the map sheets as a generic description, it may cause some problems with the coherence mentioned above, e.g. Reymann maps which were published throughout the $19^{\text {th }}$ century (Konias 2010).

The least convenient situation occurs when no map legend is added. Neither 1:84 000 nor 1:126 000 Russian topographic maps have any information concerning symbol description on either of the map sheets. In this case, the studies of the Polish Military Institute of Geography (Polish: Wojskowy Instytut Geograficzny, WIG) describing map symbols of Austrian, German and Russian maps should be used (Gasiewicz 1930; Lewakowski 1920).

The second stage of "metalegend" elaboration involves the analysis and harmonization of the acquired data as it is necessary to assign each feature class derived from one map to the others, e.g. a "railroad" from a mid-19 th $^{\text {th }}$ century map is the same as a "single-track railroad" from one made in the $20^{\text {th }}$ century so, although named differently, they both have the same meaning.

Four ways of developing a universal symbol classification can be distinguished:

1. Symbol sequence - based on the assumption that symbols on the map legend were arranged hierarchically, i.e. from the most important to the least (e.g. roads). Therefore, there is a possibility of assigning feature classes according to their order. However, map legends differ from each other in terms of category quantity, and thus the "symbol sequence" method has to be supported by additional methods.

2. Semantic analogies - requires comparing the symbols' actual meaning and significance between various maps. For this reason, it is necessary to translate map symbol descriptions, 


\section{Военно-Топографическая Карта Европейской России, $1: 126000,1912$}

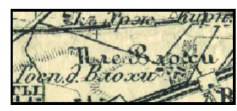

unpaved road

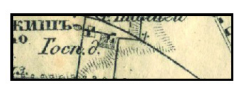

unpaved road

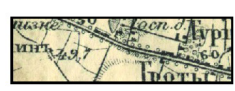

state road

\section{Karte des Westlichen Russlands, $1: 100000,1915$}

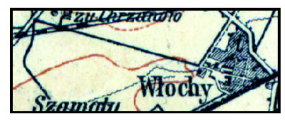

local road without ditches

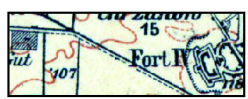

local road with ditches

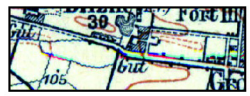

local road with ditches
Spezialkarte der ÖsterreichischUngarischen Monarchie, $1: 75000,1911$

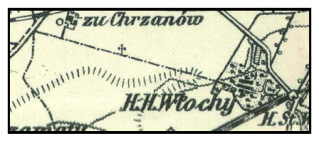

road for wagons, rural and forest road

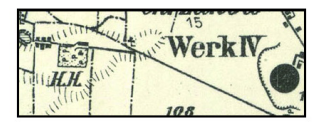

unpreserved gravel road

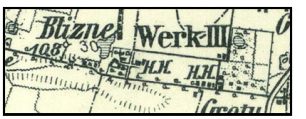

unpreserved gravel road

district road

check their meaning in dictionaries and encyclopaedias or make use of the WIG studies from the interwar period.

3. Spatial relations - involves analysing the location of the particular features based on the principle that maps issued at the same time and in the same (or similar) scale should depict the same topographic content. Therefore, a concrete object presented on map A should have the same functional meaning as the one presented on map B.

4. Combined method - implies using a "symbol sequence" approach in the first place and both "semantic analogies" and "spatial relations" to refine the classification.

In the third stage the prepared classification undergoes formalization. Harmonized and unified feature classes are to be assigned to new categories which are based on the criteria inherited from the original map symbol descriptions. Consequently the main requirements are semantic consistency as well as criteria comparability. This stage makes spatio-temporal analysis possible.

The final phase of the project is to prepare a draft of attribute table columns which will store additional information about objects as well as identify some potential subtypes. Thereby, every piece of information from the "input" data will remain on the "output" representation.

Although the use of "crowd-sourcing" in this project may only suggest a limitation to data acquisition, this approach can also be used in the process of metalegend elaboration. Registered users will be granted an opportunity to acquire spatial data, as long as they have the possibility to analyse the metalegend and submit any adjustments they deem necessary. However, the platform will be supervised by administrators and the changes will not be accepted automatically. Therefore, the concept would be to harness the power of the crowd in various ways: from data acquisition to metalegend development and validation

Case study: road network analysis in the Warsaw vicinity (turn of the $19^{\text {th }}$ and $20^{\text {th }}$ centuries)

The analysis of the road network in the Warsaw vicinity at the turn of the $19^{\text {th }}$ and $20^{\text {th }}$ centuries can serve as an example of workflow implementation being a part of a future common symbol classification covering all thematic layers and a substantial amount of maps. Three sets of topographic maps were chosen as a data source:

1. The Russian Военно-Топографическая Карта Европейской России (War-Topographic Map of the European part of Russia), scale: 1:126 000, date of issue: 1912;

2. The German Karte des Westlischen Russlands (Map of Western Russia), scale: 1:100 000, date of issue: 1915;

3. The Austrian Spezialkarte der Österreichisch-Ungarischen Monarchie (Special map of Austrio-Hungarian Monarchy), scale: 1:75 000, date of issue: 1911.

Although the scale differs across the chosen maps, they cover nearly the same content and generalization is slight or non-existent (Figure 1). In addition, the Austrian and German topographers did not have a chance to conduct field measurements in the Warsaw area - these maps were based on the Russian one and thus they inherit some of its characteristics and features (Krassowski 1973). Therefore, the similarities in this case should make the "metalegend" elaboration easier.

The first encountered obstacle was connected with data acquisition as only the German map had a legend attached to the particular map sheet. There were, however, two varying map legends for the Austrian map: one of them was a symbol description for sheets covering Italy while the other - after comparing with the "Warsaw" sheet - proved to be consistent. As mentioned before, there is no legend attached to the Russian map, so it had to be reconstructed using WIG studies from the interwar period.

The second stage of universal classification development covers the harmonization of feature classes derived from the map legends. The first attempt was made based on the "symbol sequence" approach. At first glance, all maps are characterized by diverse and incoherent object classification methods. Therefore, the "symbol sequence" method does not bring satisfying results as only the top categories were assigned accordingly (Table 1).

Another option is to assign road categories by taking into consideration their actual meaning. There is no doubt that the top category is the same on all of the maps as it refers to the Chaussee road type. Due to different classification methods (functional criterion on the Russian map, importance on the German map and qualitative on the Austrian map), the next 
Table 1. Symbol sequence method

\begin{tabular}{|c|c|c|}
\hline $\begin{array}{c}\text { Военно-Топографическая Карта } \\
\text { Европейской России }\end{array}$ & Karte des Westlischen Russlands & $\begin{array}{c}\text { Spezialkarte der Österreichisch- } \\
\text { Ungarischen Monarchie }\end{array}$ \\
\hline 1:126 000, 1912 & 1:100 000, 1915 & $1: 75000,1911$ \\
\hline Szosa państwowa (state road) & Staats-Chaussee (state road) & Chausse (road) \\
\hline Szosa pocztowa (post road) & Bezirks-Chaussee (district road) & Landstrasse (district road) \\
\hline $\begin{array}{c}\text { Szosa krajowa z rowami (district road with } \\
\text { ditches) }\end{array}$ & Grosse Landstrasse (major road) & $\begin{array}{l}\text { Erhaltener Fahrweg (preserved gravel } \\
\text { road) }\end{array}$ \\
\hline $\begin{array}{c}\text { Szosa krajowa bez rowów (district road } \\
\text { without ditches) }\end{array}$ & $\begin{array}{l}\text { Ortsverbindungsweg mit Seitengräben } \\
\text { (local road with ditches) }\end{array}$ & Besserer Fahrweg (good gravel road) \\
\hline $\begin{array}{c}\text { Droga jezdna-nieszutrowana (unpaved } \\
\text { road) }\end{array}$ & $\begin{array}{l}\text { Ortsverbindungsweg ohne Seitengräben } \\
\text { (local road without ditches) }\end{array}$ & $\begin{array}{c}\text { Nicht erhaltener Fahrweg (unpreserved } \\
\text { gravel road) }\end{array}$ \\
\hline $\begin{array}{l}\text { Droga polna lub ścieżka (rural road or } \\
\text { footpath) }\end{array}$ & $\begin{array}{l}\text { Feld- oder Waldweg (rural and forest } \\
\text { road) }\end{array}$ & $\begin{array}{l}\text { Karrenweg, Feld- und Waldweg (road for } \\
\text { wagons, rural and forest road) }\end{array}$ \\
\hline \multirow[t]{4}{*}{ Droga zimowa (winter road) } & Fussweg (footpath) & Saumweg, Reitweg (footpath, horse trail) \\
\hline & Winterweg (winter road) & Fussweg, Fussstieg (footpath) \\
\hline & & $\begin{array}{l}\text { Streckenweise in der Natur nicht } \\
\text { erkennbarer Saum oder Fussweg } \\
\text { (indistinct footpath) }\end{array}$ \\
\hline & & $\begin{array}{c}\text { Strasse in Bauausführung (road under } \\
\text { construction) }\end{array}$ \\
\hline
\end{tabular}

Table 2. Semantic analogies method

\begin{tabular}{|c|c|c|}
\hline $\begin{array}{l}\text { Военно-Топографическая } \\
\text { Карта Европейской России }\end{array}$ & Karte des Westlischen Russlands & $\begin{array}{c}\text { Spezialkarte der Österreichisch-Ungarischen } \\
\text { Monarchie }\end{array}$ \\
\hline $1: 126000,1912$ & $1: 100000,1915$ & $1: 75000,1911$ \\
\hline \multirow[t]{2}{*}{ Szosa państwowa (state road) } & \multirow{2}{*}{$\begin{array}{l}\text { Staats-Chaussee (state road) } \\
\text { Bezirks-Chaussee (district road) }\end{array}$} & Chausse (road) \\
\hline & & Landstrasse (district road) \\
\hline \multicolumn{3}{|l|}{ Szosa pocztowa (post road) } \\
\hline & Grosse Landstrasse (major road) & \\
\hline & & Erhaltener Fahrweg (preserved gravel road) \\
\hline $\begin{array}{l}\text { Szosa krajowa z rowami (district } \\
\text { road with ditches) }\end{array}$ & $\begin{array}{l}\text { Ortsverbindungsweg mit Seitengräben } \\
\text { (local road with ditches) }\end{array}$ & \\
\hline $\begin{array}{c}\text { Szosa krajowa bez rowów (district } \\
\text { road without ditches) }\end{array}$ & $\begin{array}{l}\text { Ortsverbindungsweg ohne Seitengräben } \\
\text { (local road without ditches) }\end{array}$ & \\
\hline \multirow[t]{2}{*}{$\begin{array}{l}\text { Droga jezdna-nieszutrowana } \\
\text { (unpaved road) }\end{array}$} & & Besserer Fahrweg (good gravel road) \\
\hline & & $\begin{array}{c}\text { Nicht erhaltener Fahrweg (unpreserved gravel } \\
\text { road) }\end{array}$ \\
\hline \multirow[b]{2}{*}{$\begin{array}{c}\text { Droga polna lub ścieżka (rural road } \\
\text { or footpath) }\end{array}$} & $\begin{array}{l}\text { Feld-oder Waldweg (rural and forest } \\
\text { road) }\end{array}$ & $\begin{array}{l}\text { Karrenweg, Feld- und Waldweg (road for } \\
\text { wagons, rural and forest road) }\end{array}$ \\
\hline & Fussweg (footpath) & $\begin{array}{l}\text { Saumweg, Reitweg (footpath, horse trail) } \\
\text { Fussweg, Fussstieg (footpath) } \\
\text { Streckenweise in der Natur nicht erkennbarer } \\
\text { Saum oder Fussweg (indistinct footpath) }\end{array}$ \\
\hline \multirow[t]{2}{*}{ Droga zimowa (winter road) } & Winterweg (winter road) & \\
\hline & & $\begin{array}{c}\text { Strasse in Bauausführung (road under } \\
\text { construction) }\end{array}$ \\
\hline
\end{tabular}


MISCELLANEA GEOGRAPHICA - REGIONAL STUDIES ON DEVELOPMENT

Vol. 18 • No. 4 • 2014 • pp. 34-40 • ISSN: 2084-6118 • DOI: 10.2478/mgrsd-2014-0018

Table 3. Combined method

\begin{tabular}{|c|c|c|}
\hline $\begin{array}{c}\text { Военно-Топографическая Карта } \\
\text { Европейской России }\end{array}$ & Karte des Westlischen Russlands & $\begin{array}{c}\text { Spezialkarte der Österreichisch- } \\
\text { Ungarischen Monarchie }\end{array}$ \\
\hline $1: 126000,1912$ & $1: 100000,1915$ & $1: 75000,1911$ \\
\hline Szosa państwowa (state road) & Staats-Chaussee (state road) & Chausse (road) \\
\hline Szosa pocztowa (post road) & Bezirks-Chaussee (district road) & Landstrasse (district road) \\
\hline $\begin{array}{c}\text { Szosa krajowa z rowami (district road with } \\
\text { ditches) } \\
\text { Szosa krajowa bez rowów (district road } \\
\text { without ditches) } \\
\begin{array}{c}\text { Droga jezdna-nieszutrowana (unpaved } \\
\text { road) }\end{array}\end{array}$ & Grosse Landstrasse (major road) & $\begin{array}{c}\text { Erhaltener Fahrweg (preserved gravel } \\
\text { road) } \\
\text { Besserer Fahrweg (good gravel road) } \\
\text { Nicht erhaltener Fahrweg (unpreserved } \\
\text { gravel road) }\end{array}$ \\
\hline $\begin{array}{c}\text { Droga polna lub ścieżka (rural road or } \\
\text { footpath) }\end{array}$ & $\begin{array}{c}\text { Ortsverbindungsweg mit Seitengräben } \\
\text { (local road with ditches) } \\
\text { Ortsverbindungsweg ohne Seitengräben } \\
\text { (local road without ditches) } \\
\text { Feld- oder Waldweg (rural and forest } \\
\text { road) }\end{array}$ & $\begin{array}{l}\text { Karrenweg, Feld- und Waldweg (road for } \\
\text { wagons, rural and forest road) }\end{array}$ \\
\hline \multirow[t]{3}{*}{ Droga zimowa (winter road) } & Winterweg (winter road) & \\
\hline & Fussweg (footpath) & $\begin{array}{c}\text { Saumweg, Reitweg (footpath, horse trail) } \\
\text { Fussweg, Fussstieg (footpath) } \\
\text { Streckenweise in der Natur nicht } \\
\text { erkennbarer Saum oder Fussweg } \\
\text { (indistinct footpath) }\end{array}$ \\
\hline & & $\begin{array}{c}\text { Strasse in Bauausführung (road under } \\
\text { construction) }\end{array}$ \\
\hline
\end{tabular}

few categories remain unassigned since they do not have their semantic counterparts on the other maps. However, both German and Russian maps distinguish roads with or without ditches, which seemed to be important information for the military, as well as the winter roads. On the other hand, the Austrian map gives a very detailed representation of minor roads, such as roads for wagons, footpath or forest road, unlike the Russian map, which presents rather generalized information (Table 2).

The following stage involves analysing spatial relations between roads under the assumption that those with the same route on various maps should represent the same item. However, such analysis can in fact be misleading since the map sheet date of issue is not the same as its topographic accuracy. Thereby, two maps published at the same or similar time can present different geohistorical landscapes, arising from the period of topographic field measurements. However, this factor need not be considered for the analysed maps as both of them (Austrian and German) were based on the Russian one.

Despite the same road course, the compared categories do not match each other in terms of meaning, so elaborating universal symbol classification based only on "spatial relations" analysis is impossible. No consistent relation pattern between the depicted feature classes was found. In one case the "unpaved road" (Russian map) matches "local road without ditches" (German) and "road for wagons, rural and forest road" (Austrian), while in the second case it matches "local road with ditches" (German) and "unpreserved gravel road" (Austrian) (Figure 1).

There can be two explanations: road categories could have changed as the geohistorical landscape presented on these maps comes from various periods, or there were different classification methods in Austrian, German and Russian cartography, so that the same road in fact was presented differently.

On the other hand, the differences between road categories mentioned above seem to be rather slight - all of them are minor roads used for local traffic and distinctions can be encapsulated in the existence of ditches (German map) or the function of this particular road (Austrian map).

The last method, combining all previous methods, was conducted on the basis of "metalegend" development. The main difference between this and the former approaches is that the several feature classes were now aggregated into a single category. This occurs when semantic analogies between them are strong and spatial relations indistinct (Table 3).

Generally, scale is also an important factor in the way that symbols are classified within thematic layers among the chosen maps. Generalization may affect both the legend (the amount of feature classes) and the map content (the amount of particular objects within feature classes). Maps presented in the case study are elaborated in different scales, although the generalization remains rather small and the content is nearly the same. Nevertheless, feature harmonizing was complicated due to cultural differences in terms of various criteria used by the mapmakers.

After data harmonizing, it is necessary to categorize unified feature classes, assign attributes and create subtypes which will enable the storage of every piece of the "input" information. The amount of subtypes is not fixed and depends on the characteristics of the particular class. The highest number of additional information was stored in the "local road" class, which covers the most diverse and distinct categories (Figure 2). 


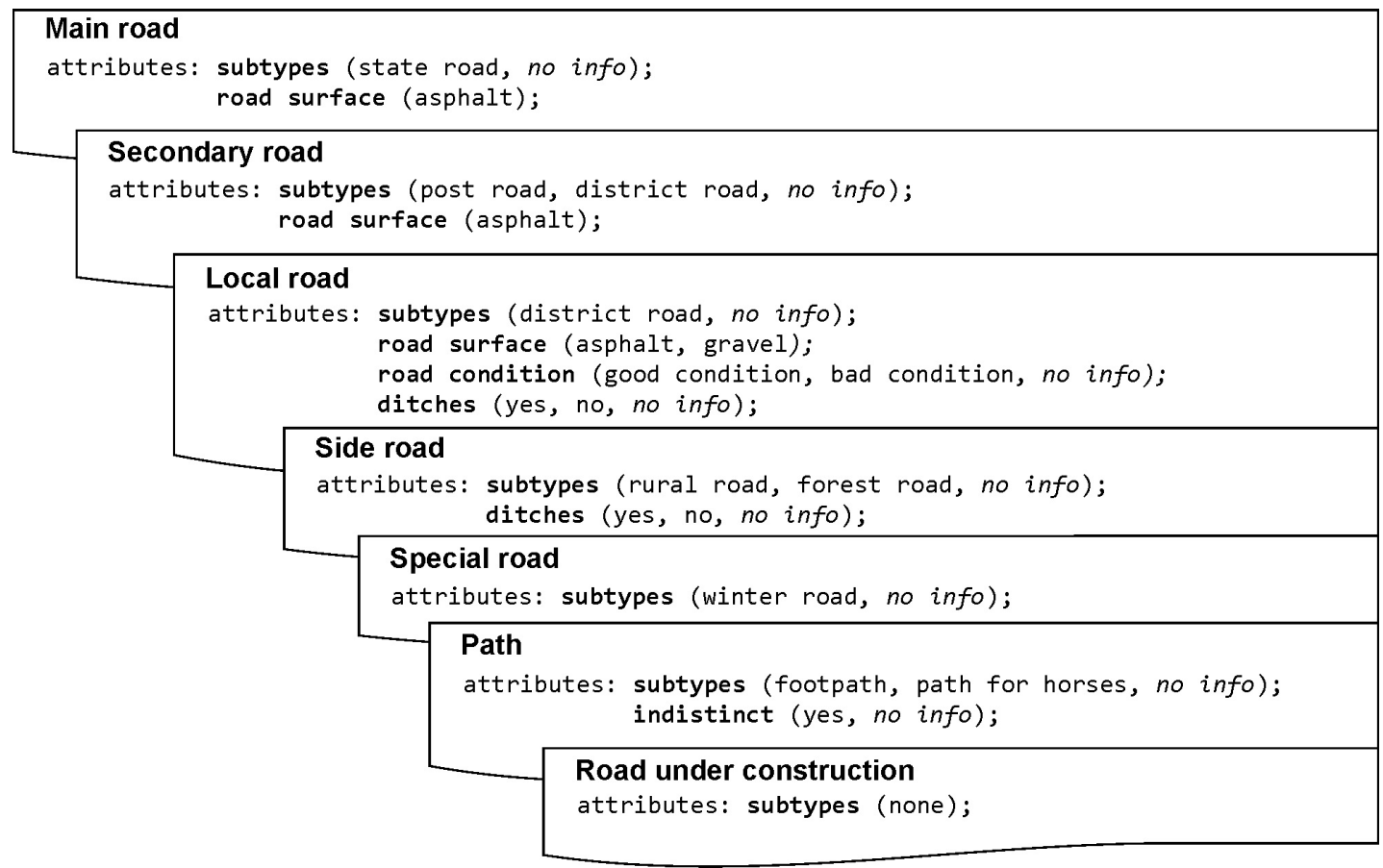

Figure 2. Proposal of a common symbol classification for a road network in the Warsaw vicinity at the turn of the $19^{\text {th }}$ and $20^{\text {th }}$ centuries

\section{Conclusions and future work}

Maps elaborated in the $19^{\text {th }}$ and early $20^{\text {th }}$ centuries are incoherent in terms of symbol classification due to various reasons: different scales, dates of issue and cultural context. Despite these disadvantages, archival maps provide much information about spatial history, and thus remain a primary data source for Internet geohistorical platforms. However, in order to be used as a background for "crowd-sourcing" data acquisition, maps have to be harmonized and a consistent "metalegend" has to be developed.

Within the research paper a proposal for the development of a common symbol classification was presented. The road network in the Warsaw vicinity at the turn of the $19^{\text {th }}$ and $20^{\text {th }}$ centuries depicted on three maps similar in terms of scale and date of issue was taken as an example of analysis. Four steps were used to develop a final "metalegend": data acquisition, map content harmonization, feature class typification and attribute table elaboration. The content of the maps was harmonized using a combination of the symbol sequence method, semantic analogies and spatial relations between objects. The analysis of semantic analogies and spatial relations appears to be the best method of symbol harmonization, although admittedly it requires further research in the field of validation.

The next stage of the project will involve more thematic layers, preparing a "metalegend" validation method as well as its implementation in the form of a cartographic data model. Therefore, developing a universal classification covering the entire map content which will be based on numerous map series from the $19^{\text {th }}$ and $20^{\text {th }}$ centuries is a challenging research project and requires further studies.

\section{References}

Buckley, A, Frye, C \& Buttenfield, B 2005, An information model for maps: towards cartographic production from GIS databases. Available from: <http://www.cartesia.org/geodoc/icc20g05/ pdf/oral/TEMA1/SESSION1/AILEEN\%22BUCKLEY.pdf>. [13 November 2013].

Chwalba, A 2005, Historia Polski 1795-1918, Wydawnictwo Literackie, Kraków.

Dunn, C 2007, 'Participatory GIS - a people's GIS?', Progress in Human Geography, vol. 31, no. 5, pp. 616-637.

Gąsiewicz, S 1930, Znaki topograficzne map, Główna Księgarnia Wojskowa, Warszawa.

Gołębiowska, I, Karsznia. I, Panecki, T \& Mikiewicz, D 2012, 'Towards historical GIS platform in Poland', ServiceOriented Mapping 2012, ed M Jobst, Jobst Media, Vienna pp. 417-430.

Gregory, I 2005, A place in history: A guide to using GIS in historical research, Queen's University, Belfast.

Gregory, I \& Healey, R 2007, 'Historical GIS: structuring, mapping and analyzing geographies of the past', Progress in Human Geography, vol. 31, no. 5, pp. 638-653.

Gregory, I \& Southall, H 2000, The Great Britain Historical GIS. Available from: <http://www.gbhgis.org>. [13 November 2013].

Cartoninjas 2013. Available from: <http://www.cartoninjas.net/>. [13 November 2013].

Kent, AJ \& Vujakovic, P 2009, 'Stylistic Diversity in European State 1 : 50000 Topographic Map', The Cartographic Journal, vol. 46, no. 3, pp. 179-213

Knowles, AK 2007, Placing history: how maps, spatial data, and GIS are changing historical scholarship, ESRI Press, Redlands.

Konias, A 2010, Kartografia topograficzna państwa i zaboru pruskiego od II połowy XVIII do połowy XX wieku, Wydawnictwo Naukowe Akademii Pomorskiej, Słupsk.

Krassowski, B 1973, Polska Kartografia Wojskowa w latach 1919-1945, Wydawnictwo Ministerstwa Obrony Narodowej, Warszawa. 
Krassowski, B \& Tomaszewska, M 1979, Mapy topograficzne ziem polskich 1871-1945, Biblioteka Narodowa, Warszawa.

Lewakowski, J 1920, Klucz znaków przyjętych dla map, Księgarnia J. Czarneckiego, Kraków.

National Historical Geographic Information System. Available from: <https://www.nhgis.org/>. [13 November 2013].

OpenStreetMap. Available from: <http://www.openstreetmap. org>. [13 November 2013].

Robinson, AC, Pezanowski, S, Troedson, S, Bianchetti, R, Blanford, J, Stevens, J, Guidero, E, Roth, RE \& MacEachren, AM 2013, 'Symbol Store: sharing map symbols for emergency management', Cartography and Geographic Information Science, vol. 40, no. 5, pp. 415-426

Spoerhase, C 2008, 'Presentism and Precursorship in Intellectual History', Culture, Theory and Critique, vol. 49, no. 1, pp. 49-72.
Szady, B 2008, 'Zastosowanie systemów informacji geograficznej w geografii historycznej', Polski Przegląd Kartograficzny, vol. 40, no. 3, pp. 279-283.

Szady, B 2010, 'Granice powiatu łukowskiego w II połowie XVIII wieku - model liniowy i sieciowy', Narrata de fontibus hausta. Studia nad problematyką kościelną, polityczną $i$ archiwistyczną ofiarowane Janowi Skarbkowi w siedemdziesiątą rocznicę urodzin, eds A Barańska \& W Matwiejczyk, KUL, Lublin, pp. 831-845.

Zachwatowicz, M 2012, 'Detekcja historycznych przemian pokrycia terenu z zastosowaniem elementów logiki rozmytej', Źródła kartograficzne w badaniach krajobrazu kulturowego, Komisja Krajobrazu Kulturowego Polskiego Towarzystwa Geograficznego, Sosnowiec. 